\title{
Review Study: Clinical Assessment of Patients With Thoracic Outlet Syndrome
}

\author{
Narges Ghamari ${ }^{1}$, Seyed Ali Hosseini ${ }^{1 *}$, Fereydun Layeghi² ${ }^{2}$ Hamid Reza Khankeh ${ }^{3}$, Laleh Lajvardi ${ }^{4}$ \\ 1. Department of Occupational Therapy, Univercity of Social Welfare and Rehabilitation Sciences, Tehran, Iran \\ 2. Department of Clinical Sciences, Univercity of Social Welfare and Rehabilitation Sciences, Tehran, Iran. \\ 3. Research Center in Emergency and Disaster Health, Univercity of Social Welfare and Rehabilitation Sciences, Tehran, Iran \\ 4. Department of Occupational Therapy, School of Rehabilitation Sciences, Iran University of Medical Sciences, Tehran, Iran.
}

CItation: Ghamari N, Hosseini SA, Layeghi F, Khankeh HR, Lajvardi L. Clinical Assessment of Patients With Thoracic Outlet Syndrome. Physical Treatments. 2016; 5(4):189-196. https://dx.crossref.org/10.15412/J.PTJ.07050401

dol': https://dx.crossref.org/10.15412/J.PTJ.07050401

Article info:

Received: 08 Aug. 2015

Accepted: 24 Nov. 2015

Keywords:

Thoracic outlet syndrome, Evaluation, Assessment, Outcome measure

\begin{abstract}
A B S T RA C T
Purpose: Thoracic outlet syndrome is one of the most controversial topics in clinical medicine due to its difficult assessment and management. The appropriate treatment depends on accurate and comprehensive assessment. This study aimed to review the current assessments of these patients.

Methods: This study was conducted by review of the articles published between 1990 and 2014. Search was conducted by keywords such as assessment, evaluation, outcome measure, tool, thoracic outlet syndrome, non-surgical treatments, conservative, and rehabilitation. In this regard, internal and external databases, including PubMed, OVID, ProQuest, Web of science, Elsevier, OT seeker, SID, Magiran, Iran Medex, Medlib, and Google scholar were used.

Results: The results showed that the most common assessments for these patients in a clinical and research setting included a thorough review of history and subjective evaluation. No specific tools were found for patients with thoracic outlet syndrome but 5 generic outcome measures were suggested to measure the outcome of interventions in these patients.

Conclusion: At present, comprehensive evaluation of patients with thoracic outlet syndrome needs different assessments and using the generic questionnaire that is designed for people with orthopedic conditions. Therefore, a comprehensive assessment tool with a holistic view and specific for patients with thoracic outlet syndrome is necessary.
\end{abstract}

\section{Introduction}

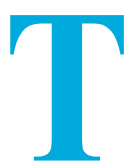

horacic outlet syndrome is caused by compression on blood vessels and nerves in thoracic outlet area $[1,2]$. The factors which cause the compression in this area include congenital abnormalities associated with musculoskeletal structure, muscles, and other acquired factors [1, 3-5]. Depending on the structures under pressure, this syndrome categorizes into neurogenic thoracic outlet syndrome, vascular thoracic outlet syndrome, and disputed thoracic outlet syndrome $[3,6]$.

\section{* Corresponding Author:}

Seyed Ali Hosseini, PhD

Address: Department of Clinical Sciences, Univercity of Social Welfare and Rehabilitation Sciences, Kodakyar Ave., Daneshjo Blvd., Evin, Tehran, Iran. Phone: +98 (917) 7177197

E-mail:alihosse@gmail.com 
Neurogenic thoracic outlet syndrome is caused by pressure on the brachial-plexus nerves and Vascular thoracic outlet syndrome is the result of pressure on the vessels. In the absence of the bones and electrodiagnostic abnormalities, neurogenic thoracic outlet syndrome is often called the non-specific thoracic outlet syndrome [7]. The patient's primary complaints are pain, feeling of heaviness and fatigue, and weakness in the neck, shoulders, arms, and hands $[1,3,8,9]$. Pain is one of the most common symptoms in these patients which can lead to clear and specific inability in performing daily activities $[1,3]$. Neurogenic and vascular thoracic outlet syndrome is primarily managed with surgical treatment and then non-surgical while the non-specified one is managed by non-surgical treatment and only those people who are resistant to nonoperative treatment, may need to have surgery [4]. Therefore, non-surgical treatment of thoracic outlet syndrome is one the most accepted treatments. These treatments include occupational therapy, chiropractic, complementary and alternative therapies, as well as physiotherapy.

Since thoracic outlet syndrome causes some problems for therapists with regard to its assessment and management; it is one of most controversial clinical issues in medicine $[3,6,12]$. The assessment, treatment, and the successful prevention of the symptoms of thoracic outlet syndrome are clinically challenging. Lack of high quality clinical trials in the treatment of the thoracic outlet syndrome has failed the researchers to compare the undergone treatments in people suffering from thoracic outlet syndrome and offer the best treatment. Therefore, decisions about choosing the proper treatment would be based on the patient's preferences and health providers' diagnosis [3]. Also, choosing the proper treatment depends on a comprehensive and detailed assessment. The evaluation process includes $20 \%$ of the total treatment process [13]. Using the right, valid, and reliable tools can be influential in enhancing the clinicians and researchers' ability in determining the problem patterns in patients [14]. Accordingly, this study by reviewing the available assessments in these patients tried to provide the researchers and the clinicians with accurate data concerning the assessment tools and the advantages and disadvantages of each tool.

\section{Materials and Methods}

The narrative method has been used in this study. Evidence-based assessments used in patients with thoracic outlet syndrome were organized and searched from published articles since 1990 to 2014. The used internal and external databases were PubMed OVID, ProQuest, Web of Science, Elsevier, OT seeker, SID, Magiran, Iran Medex, Medlib, and Google Scholar. The present study included those studies which were published from 1990 to 2014 at the mentioned databases.

The keywords which were used separately and in combination were evaluation (tool, outcome measure, evaluation, and assessment), thoracic outlet syndrome, and non-surgical treatments (rehabilitation, conservative) The inclusion criteria included the abstracts of full text of articles in Persian and English that evaluated patients with thoracic outlet syndrome. And the exclusion criteria included the theoretical or cognitive studies, also studies on surgery, studies on the development of the assessment instrument, inappropriate and unrelated topics and articles other than Persian and English. Given the fact that the purpose of this study was to review the evaluation of the patients with thoracic outlet syndrome, to complete the required information, the related web sites and books which studied these patients were searched and studied, too.

\section{Results}

In this study, the abstract sections of 272 articles were analyzed after reading the articles' titles and deletion of unrelated ones. Among these articles, only three articles had the inclusion criteria about the patients' evaluation [15], and in article 2 both the evaluation and treatment $[5,16]$. Among the books, which analyzed the evaluation of thoracic output syndrome, two books of "Rehabilitation and Upper Extremity" [17] and "The Thoracic Output Syndrome" were studied [18]. The results showed that the most common evaluation for these patients were done in clinical and research environments such as individual's history and background, objective and subjective evaluation such as the nature of the pain, and also the intensity of the pain using the visual analogue scale, examination of the vascular status, evaluation of sensory position (the discrimination of two points and vibration), the examination of paresthesia, amount of swelling or puffiness in the arm or hand, the amount of hand fatigue, atrophy in arm or hand, the range and the strength of the muscles in the neck, arm, elbow, and hand, examination in the individual's occupational position, posture, muscle shortness, muscle tightness, nerves' tension tests stimulating tests such as Ruth and Edson [15-18].

No specific measurement for the patients with thoracic outlet syndrome was found but two general measuring instruments of the patient specific functional scale (PSFS), and shoulder rating questionnaire (SRQ), as well as outcome measure of patients were suggested by Watson [5] in 2010. In addition, to evaluate these patients, the standard care level of the patients with thoracic outlet syndrome affiliated to the Rehabilitation Department of The Brighten and Women's Hospital in 2007 has recommended three 
Table 1. The characteristics of the used sources in this study.

\begin{tabular}{|c|c|c|c|c|c|c|}
\hline Title & $\begin{array}{c}\text { Article or } \\
\text { Book }\end{array}$ & $\begin{array}{c}\text { Published } \\
\text { Year }\end{array}$ & The Authors & Publication & Subject & Results \\
\hline $\begin{array}{l}\text { Evaluation of } \\
\text { patients with } \\
\text { thoracic outlet } \\
\text { syndrome }\end{array}$ & Article & 1993 & $\begin{array}{c}\text { Ovak CB, } \\
\text { Mackinnon SE, } \\
\text { Patterson GA }\end{array}$ & $\begin{array}{c}\text { The Journal of Hand } \\
\text { Surgery }\end{array}$ & $\begin{array}{l}\text { Evaluation of individu- } \\
\text { als with thoracic outlet } \\
\text { syndrome }\end{array}$ & $\begin{array}{l}\text { This paper examined the assess- } \\
\text { ments which have been con- } \\
\text { ducted on } 50 \text { patients. These } \\
\text { assessments were physical as- } \\
\text { sessments of perception and } \\
\text { strength as well as pain assess- } \\
\text { ment, which most of them were } \\
\text { about the patients with normal } \\
\text { thoracic outlet syndrome. }\end{array}$ \\
\hline $\begin{array}{l}\text { Evaluation and } \\
\text { treatment for } \\
\text { thoracic outlet } \\
\text { syndrome }\end{array}$ & Article & 2002 & Powers WS & $\begin{array}{l}\text { Available from: http:// } \\
\text { physical-therapy. } \\
\text { advanceweb.com/ } \\
\text { Article/Evaluation-and- } \\
\text { Treatment-for-Thoracic- } \\
\text { Outlet-Syndrome.aspx }\end{array}$ & $\begin{array}{l}\text { Evaluation and treat- } \\
\text { ment of thoracic outlet } \\
\text { syndrome }\end{array}$ & $\begin{array}{l}\text { In this article, the accurate his- } \\
\text { tory and physical evaluation of } \\
\text { the patient, such as range of mo- } \\
\text { tion, muscle strength, posture } \\
\text { analysis, muscle flexibility, pain, } \\
\text { muscle atrophy and weakness, } \\
\text { description of work position as } \\
\text { well as job requirements and } \\
\text { physical condition necessary for } \\
\text { evaluating patients with thoracic } \\
\text { outlet syndrome are explained. }\end{array}$ \\
\hline $\begin{array}{l}\text { Thoracic outlet } \\
\text { syndrome part } \\
\text { 2: Conservative } \\
\text { management of } \\
\text { thoracic outlet }\end{array}$ & Article & 2010 & $\begin{array}{l}\text { Watson LA, Piz- } \\
\text { zari T, Balster S }\end{array}$ & Manual Therapy Journal & $\begin{array}{l}\text { Management of tho- } \\
\text { racic outlet syndrome }\end{array}$ & $\begin{array}{l}\text { Referring to the evaluation, such } \\
\text { as the scapula and the scope and } \\
\text { strength of shoulder muscles in } \\
\text { patients with thoracic outlet syn- } \\
\text { drome }\end{array}$ \\
\hline
\end{tabular}

\begin{tabular}{|c|c|c|c|c|c|c|}
\hline $\begin{array}{l}\text { Rehabilitation } \\
\text { of the hand and } \\
\text { upper extremity }\end{array}$ & Book & 2012 & $\begin{array}{c}\text { Skirven TM, } \\
\text { Osterman AL, } \\
\text { Fedorczyk JM, } \\
\text { Amadio PC }\end{array}$ & Philadelphia: Mosby & $\begin{array}{l}\text { Hand and upper ex- } \\
\text { tremity rehabilitation }\end{array}$ & $\begin{array}{l}\text { Part } 2 \text { of this book assesses the } \\
\text { damage, such as history taking, } \\
\text { physical assessment, edema; } \\
\text { range of motion, muscle testing } \\
\text { and evaluation of sense. Chap- } \\
\text { ter } 9 \text { discusses assessment tests, } \\
\text { such as pain and its specific char- } \\
\text { acteristics. In addition, Chapter } \\
54 \text { dedicated to the evaluation } \\
\text { and treatment of thoracic outlet } \\
\text { syndrome which is discussed. }\end{array}$ \\
\hline $\begin{array}{l}\text { Thoracic Outlet } \\
\text { Syndrome }\end{array}$ & Book & 2013 & $\begin{array}{l}\text { Illig KA, } \\
\text { Thompson } \\
\text { RW, Freischlag } \\
\text { JA, Donahue } \\
\text { DM, Jordan SE, } \\
\text { Edgelow PI }\end{array}$ & London: Springer & Outlet Syndrome Cases & $\begin{array}{l}\text { The assessment and treatment } \\
\text { of a variety of thoracic outlet } \\
\text { syndromes. In every part, the } \\
\text { physical assessment of each type } \\
\text { of thoracic outlet syndrome has } \\
\text { been mentioned. }\end{array}$ \\
\hline
\end{tabular}

general measuring scales, including shoulder pain and disability index (SPADI), simple shoulder test (SST), and American shoulder and elbow surgeons (ASES). Moreover, the "arm, shoulder, and hand" questionnaire has been used in some studies conducted on the patients with thoracic outlet syndrome [20-22]. In Table 1, the characteristics of the resources and in Table 2, two characteristics on evaluating the treatment outcomes [23-26] are presented.

\section{Discussion}

Our review study showed that most evaluations and the used assessments for patients with thoracic outlet syndrome included physical evaluations based on the level of the injury and body disorder. The same results have been reported out of the previous studies on patients with injuries in the upper extremity [11, 15, 27-31]. Regular assessments based on damaged and physical disorders do not possess enough validity and reliability [32]. In addition, due to the use of variety of assessments and evaluations to determine the patient's condition, these kinds of evaluations will be very time-consuming and costly. On the other hand, none of these evaluations reveal the patient's real use of the upper extremities in daily life [33], let alone the contradictory relations between the measuring instruments with regard to the range, strength, and function. Thus, the functional outcome evaluation instruments are often used as the effective 
Table 2. The characteristics of measurement tools used to assess the outcome of patients with thoracic outlet syndrome.

\begin{tabular}{|c|c|c|c|c|c|}
\hline & $\begin{array}{l}\text { Outcome Measure- } \\
\text { ment Instrument }\end{array}$ & Test Description & Uses & Test-Retest Reliability & Instrument Type \\
\hline 1 & $\begin{array}{l}\text { Patient's specific } \\
\text { performance }\end{array}$ & $\begin{array}{l}\text { The disease testing activities; where } \\
\text { the problem is and then list the issue } \\
\text { on the basis of the grading scale vi- } \\
\text { sual comparison. In this test, the pa- } \\
\text { tient lists the activities which he or } \\
\text { she participates in and then grades } \\
\text { the level of the problem based on } \\
\text { the visual comparison scale. Zero } \\
\text { means that the patient is not able } \\
\text { to do any activities and } 10 \text { means he } \\
\text { or she is able to do the activities the } \\
\text { same as before. }\end{array}$ & $\begin{array}{l}\text { It is designed for } \\
\text { measuring the dis- } \\
\text { ability in patients with } \\
\text { orthopedic problem } \\
\text { and the activity limita- } \\
\text { tion and measuring its } \\
\text { function. }\end{array}$ & $\begin{array}{l}\text { Inter correlation coef- } \\
\text { ficient: } \\
0.71-0.7\end{array}$ & General \\
\hline 2 & Grading scale shoulder & $\begin{array}{l}\text { This instrument has } 18 \text { items. Five } \\
\text { items are for evaluating the pain in } \\
\text { shoulder, } 7 \text { items for evaluating the } \\
\text { daily life activities, } 3 \text { items for cre- } \\
\text { ative or sport activities, and } 4 \text { items } \\
\text { for evaluating jobs. }\end{array}$ & $\begin{array}{l}\text { This instrument } \\
\text { has been used and } \\
\text { tested for validity and } \\
\text { responding to changes } \\
\text { in a Developed Ortho- } \\
\text { pedic Center. }\end{array}$ & $\begin{array}{l}\text { Inter correlation coef- } \\
\text { ficient: } \\
0.83\end{array}$ & General \\
\hline 3 & $\begin{array}{l}\text { Shoulder pain and dis- } \\
\text { ability index (SPADI) }\end{array}$ & $\begin{array}{l}\text { This is a self-report instrument. It has } \\
13 \text { items. Five items are designed for } \\
\text { evaluating pain, and } 8 \text { items for func- } \\
\text { tion. Responding is based on the vi- } \\
\text { sual comparing index. }\end{array}$ & $\begin{array}{l}\text { It is designed specifi- } \\
\text { cally for evaluation of } \\
\text { the symptoms and } \\
\text { function of shoulder. }\end{array}$ & $\begin{array}{l}\text { Inter correlation coef- } \\
\text { ficient: } \\
0.84-0.95\end{array}$ & General \\
\hline 4 & $\begin{array}{l}\text { Simple shoulder test } \\
\text { (SST) }\end{array}$ & $\begin{array}{l}\text { This instrument has } 12 \text { items. Two } \\
\text { items are about functions associated } \\
\text { with pain, } 7 \text { with power/function, } \\
\text { and } 3 \text { with range of motion. }\end{array}$ & $\begin{array}{l}\text { It is designed for } \\
\text { measuring the injured } \\
\text { functional shoulder } \\
\text { limitation during daily } \\
\text { life activities. }\end{array}$ & $\begin{array}{l}\text { Inter correlation coef- } \\
\text { ficient: } \\
0.97-0.99\end{array}$ & General \\
\hline 5 & $\begin{array}{l}\text { American shoulder and } \\
\text { elbow surgeons (ASES) }\end{array}$ & $\begin{array}{l}\text { It has two parts. One part is com- } \\
\text { pleted in a self-report manner by the } \\
\text { patient and includes } 6 \text { items for eval- } \\
\text { uating pain, } 2 \text { items for instability, } 10 \\
\text { items for evaluating daily life activ- } \\
\text { ity. The second part is evaluated by } \\
\text { the evaluator and includes } 5 \text { items } \\
\text { for measuring the motion range, } 11 \\
\text { items for examining the symptoms, } 5 \\
\text { items for evaluating the power, and } \\
8 \text { items and } 1 \text { open item for evaluat- } \\
\text { ing instability. }\end{array}$ & $\begin{array}{l}\text { It is designed for all } \\
\text { patients with problem } \\
\text { in shoulder without } \\
\text { attention to diagnosis. }\end{array}$ & $\begin{array}{l}\text { Inter correlation coef- } \\
\text { ficient: } \\
0.84-0.96\end{array}$ & General \\
\hline 6 & $\begin{array}{l}\text { Disability of arm, } \\
\text { shoulder, and hand } \\
\text { (DASH) }\end{array}$ & $\begin{array}{l}\text { It is a self-report instrument. It has } \\
30 \text { items. Six items evaluate the } \\
\text { symptoms and } 24 \text { items evaluate the } \\
\text { patient's performance and function. }\end{array}$ & $\begin{array}{l}\text { It evaluates the } \\
\text { physical functions and } \\
\text { symptoms in patients } \\
\text { with upper extrem- } \\
\text { ity musculoskeletal } \\
\text { disorders }\end{array}$ & $\begin{array}{l}\text { Inter correlation coef- } \\
\text { ficients: } \\
0.93-0.98\end{array}$ & General \\
\hline
\end{tabular}

treatment measuring mean instrument in patients with different pathologies in shoulder.

Although the patient's general self-report functional conditions are valid and reliable, they have some limitations, for example, each instrument does possess unique characteristics. Therefore, researchers must be assured of its use in the target population [32]. The results of this study showed that currently there is no outcome instrument test specific to patients with thoracic outlet syndrome in the database. This has also been reported in Watson study [5]. Thus, considering the lack of instruments specific to eval- uate the outcome for these patients, a general outcome instrument is utilized by the scientists and therapists.

Among the various instruments for measuring the outcome for orthopedic problems, 6 functional outcome instruments have been suggested for these patients. These instruments are generally designed, validated, and reliable for orthopedic problems. However, they have some limitations such as complex grading, trust in the visual comparative scale, repeated questions, lack of feedback for the patients, and optional decision making in weighing different aspects of test, for example pain in facing 
questions [24]. These instruments are recommended for patients with thoracic outlet syndrome, however none of them has been validated and reliable in these patients and using them requires more research on their psychometric properties in these patients. Although, the studies showed that the psychometric properties of these instruments are acceptable for clinical use [23, 25, 34], the clinical use of them requires more research and examinations. For instance, the shortness of questionnaire, simple answering with yes/no, and very simple grading in "simple shoulder test" makes this questionnaire an attractive research clinical instrument but in the systematic-review studies, the least detectable change (MDC) and the least minimal clinically important difference (MCID) are not defined [34].

In addition, the studies indicate that this instrument cannot show the different levels of intensity in patients with one condition of the illness. This is important when the researcher want to use this test for evaluating the changes before and after a process. Moreover, this instrument is not responsive to changes happening in young people. Therefore, if the target population is young, the instrument may not be appropriate for evaluating the functional changes over time. That is why the other outcome measurement instruments in clinical research are also necessary [24].

Although the "patient-specific performance index" has been validated and reliable and used for different parts of the body, the research has not shown its validity for various populations [35]. This instrument is more responsive than other similar ones in assessing the shoulder when there is low limitation in activities [36]. Given that this instrument is not validated for patients with thoracic outlet syndrome, its use is uncertain in these patients. The psychometric properties of "American shoulder and elbow surgeons" questionnaire have been examined and analyzed for some shoulder problems such as shoulder rotator cuff diseases, shoulder instability, and glenohumeral arthritis. Also, it has been reported acceptable for assessing the outcomes in these patients [37]. However, it has not been examined in patients with thoracic outlet syndrome. This questionnaire is translated into Persian in Iran and its Persian version Cronbach $\alpha$ coefficient has been reported as 0.91 . A strong relationship has been reported between the Persian version of this questionnaire and "the hand, arm, and shoulder disability questionnaire" [38]. The "hand, arm, and shoulder disability questionnaire" has a good validity and is able to determine the different severity of patient's problem, and also the relationship between the pain and the function [39]. This questionnaire has been validated and is reliable in Iran and its Persian version Cronbach $\alpha$ coefficient has been reported as 0.96 [40]. It is widely used as the outcome evaluating instrument by working therapists at the rehabilitation field [41]. Although this questionnaire has not been validated for patients with thoracic outlet syndrome, it is commonly used in different studies on these patients [20-22-42].

In other studies, the "shoulder grading scale" and "shoulder pain and disability index" questionnaire have demonstrated a high response to the changes in patients with shoulder problems. The "shoulder pain and disability" has an easier grading and more acceptance compared to the "shoulder grading" questionnaire for participants and is completed faster but it has less validity. Responding to changes over time and the construct validity of both questionnaires are identical [25]. The "shoulder pain and disability index" has also been translated into Persian in Iran and the Persian version Cronbach $\alpha$ coefficient has been reported as 0.94 [43]. Other questionnaires have not been validated in Iran. In general, none of the suggested instruments, for evaluating patients with thoracic outlet syndrome, has been validated in these patients. Hence, their use for this population needs further studies.

In recent years, the emphasis has been put on health outcome measurement instruments [17], which in addition to examining the patient's health condition, is significant for them, too [13]. Because the health outcome measuring instruments are subjective and completed in self-report form by the patients, in addition to the patients' general look and all aspects of their disabilities [44], it can be significant for the patients by involving them in the process of evaluation and treatment [17]. These instruments are both general and disease-specific [45]. Therefore, besides measuring the validity of the mentioned general questionnaire, which is recommended for patients with thoracic outlet syndrome, more studies are highly suggested on designing the measurement outcome instrument specific to these patients, because no measuring-outcome one for these patients exists now.

Designing a disease-specific outcome assessment instrument provides more accurate information on disease condition and its changes to therapists and researchers; it also avoids the unnecessary evaluation and delivers better outcome assessment. In addition, it will provide a unique instrument for evaluating the outcome of the treatments in research studies [3] so that it will be possible to compare results of the studies with each other and suggest the best treatment course [46].

Currently, a comprehensive evaluation of patients with thoracic outlet syndrome demands more variety of assessments and evaluations tools and using questionnaires, which are designed for patients with orthopedic 
problems. Given that the lack of comprehensive and holistic evaluation lead to failure in evaluating the results of the treatment, a comprehensive assessment and evaluation with a holistic view specific to disease seems necessary. Limited access to the full text of the articles was one of the major limitations in this study.

\section{Acknowledgements}

We highly appreciate authors who assisted us in their research by providing their articles, and those ones who helped us with writing this article.

\section{Conflict of Interest}

The authors declared no conflict of interests.

\section{Reference}

[1] Liebenson CS. Thoracic outlet syndrome: diagnosis and conservative management. Journal of Manipulative and Physiological Therapeutics. 1988; 11(6):493-9. PMID: 3075651

[2] Cho YJ, Lee HJ, Gong HS, Rhee SH, Park SJ, Baek GH. The radiologic relationship of the shoulder girdle to the thorax as an aid in diagnosing neurogenic thoracic outlet syndrome. Journal of Hand Surgery. 2012; 37(6):1187-193. doi 10.1016/j.jhsa.2012.02.022

[3] Povlsen B, Belzberg A, Hansson T, Dorsi M. Treatment for thoracic outlet syndrome. The Cochrane Database of Systematic Reviews. 2010; 1:CD007218. doi: 10.1002/14651858. CD007218

[4] Hooper TL, Denton J, McGalliard MK, Brismee JM, Sizer Jr PS. Thoracic outlet syndrome: a controversial clinical condition. Part 2: non-surgical and surgical management. Journal of Manual \& Manipulative Therapy. 2010; 18(3):132-38. doi: 106698110x12640740712338

[5] Watson LA, Pizzari T, Balster S. Thoracic outlet syndrome part2; conservative management of thoracic outlet. Manual Therapy. 2010; 15(4):305-14. doi: 10.1016/j.math.2010.03.002

[6] Ozoa G, Alves D, Fish DE. Thoracic outlet syndrome. Physical Medicine \& Rehabilitation Clinics of North America. 2011; 22(3):473-83. doi: 10.1016/j.pmr.2011.02.010

[7] Landry GJ, Moneta GL, Taylor LM, Edwards JM, Porter JM. Long-term functional outcome of neurogenic thoracic outlet syndrome in surgically and conservatively treated patients. Journal of Vascular Surgery. 2001; 33(2):312-17. doi: 10.1067/ mva.2001.112950

[8] Crosby CA, Wehbe MA. Conservative treatment for thoracic outlet syndrome. Hand Clinics. 2004; 20(1):43-49. doi: 10.1016/s0749-0712(03)00081-7

[9] Streit RS. NTOS symptoms and mobility: a case study on neurogenic thoracic outlet syndrome involving massage therapy. Journal of Bodywork \& Movement Therapies. 2014; 18(1):42-48. doi: 10.1016/j.jbmt.2013.04.007

[10] van der Windt DA, van der Heijden GJ, de Winter AF, Koes BW, Deville W, Bouter LM. The responsiveness of the Shoulder Disability Questionnaire. Annals of the Rheumatic Diseases. 1998; 57(2):82-87. doi: 10.1136/ard.57.2.82

[11] Hooper TL, Denton J, McGalliard MK, Brismee JM, Sizer PS. Thoracic outlet syndrome: a controversial clinical condition. Part 1: anatomy, and clinical examination/diagnosis Journal of Manual \& Manipulative Therapy. 2010; 18(2):7483. doi: $10.1179 / 106698110 \times 12640740712734$

[12] Vanti C, Natalini L, Romeo A, Tosarelli D, Pillastrini P. Conservative treatment of thoracic outlet syndrome. A review of the literature. European Journal of Physical \& Rehabilitation Medicine. 2007; 43(1):55-70. PMID:16955064

[13] Larsson TJ, Bjornstig U. Persistent medical problems and permanent impairment five years after occupational injury. Scandinavian Journal of Public Health. 1995; 23(2):121-28. doi: $10.1177 / 140349489502300207$

[14] Thomas A. Are occupational therapists' assessments occupation focused? Plymouth Student Journal of Health \& Social Work. 2012; 4:46-60.

[15] Novak CB, Mackinnon SE, Patterson GA. Evaluation of patients with thoracic outlet syndrome. Journal of Hand Surgery. 1993; 18(2):292-99. doi: 10.1016/0363-5023(93)90364-9

[16] Powers WS. Evaluation and treatment for thoracic outlet syndrome. Advanced Physical Therapy Rehab Medicine. 2002; 13(5):43.

[17] Skirven TM, Osterman AL, Fedorczyk JM, Amadio PC. Rehabilitation of the hand and upper extremity. 6th ed. Philadelphia: Mosby; 2012.

[18] Illig KA, Thompson RW, Freischlag JA, Donahue DM, Jordan SE, Edgelow PI. Thoracic outlet syndrome. London: Springer; 2013.

[19] Brigham and Women's Hospital. Standard of Care: Thoracic Outlet Syndrome (non-operative). Boston: The Brigham \& Women's Hospital Inc; 2007.

[20] Cordobes-Gual J, Lozano-Vilardell P, Torreguitart-Mirada N, Lara-Hernandez R, Riera-Vazquez R, Julia-Montoya J. Prospective study of the functional recovery after surgery for thoracic outlet syndrome. European Journal of Vascular and Endovascular Surgery. 2008; 35(1):79-83. doi: 10.1016/j. ejvs.2007.07.013

[21] Glynn RW, Tawfick W, Elsafty Z, Hynes N, Sultan S. Supraclavicular scalenectomy for thoracic outlet syndrome--functional outcomes assessed using the DASH scoring system. Vascular and Endovascular Surgery. 2012; 46(2):157-62. doi: $10.1177 / 1538574411434164$

[22] Finlayson HC, O'Connor RJ, Brasher PM, Travlos A. Botulinum toxin injection for management of thoracic outlet syndrome: a double-blind, randomized, controlled trial. Pain. 2011; 152(9):2023-028. doi: 10.1016/j.pain.2011.04.027

[23] Angst F, Schwyzer HK, Aeschlimann A, Simmen BR, Goldhahn J. Measures of adult shoulder function: Disabilities of the Arm, Shoulder, and Hand Questionnaire (DASH) and its short version (QuickDASH), Shoulder Pain and Disability Index (SPADI), American Shoulder and Elbow Surgeons 
(ASES) Society standardized shoulder assessment form, Constant (Murley) Score (CS), Simple Shoulder Test (SST), Oxford Shoulder Score (OSS), Shoulder Disability Questionnaire (SDQ), and Western Ontario Shoulder Instability Index (WOSI). Arthritis Care Research. 2011; 63(11):174-88. doi: $10.1002 /$ acr.20630

[24] Godfrey J, Hamman R, Lowenstein S, Briggs K, Kocher M. Reliability, validity, and responsiveness of the simple shoulder test: psychometric properties by age and injury type. Journal of Shoulder \& Elbow Surgery. 2007; 16(3):260-67. doi: $10.1016 /$ j.jse.2006.07.003

[25] Paul A, Lewis M, Shadforth MF, Croft PR, Windt DA, Hay EM. A comparison of four shoulder-specific questionnaires in primary care. Annals of the Rheumatic Diseases. 2004; 63(10):1293-299. doi: 10.1136/ard.2003.012088

[26] de Siqueira DC, Baptista AF, Souza I, Sa KN. Translation, cultural adaptation, validity and reliability of the shoulder rating questionnaire for use in Brazil. Revista Brasileira de Reumatologia. 2014; 54(6):415-23. doi: 10.1016/j. rbre.2014.04.006

[27] Axelrod DA, Proctor MC, Geisser ME, Roth RS, Greenfield LJ. Outcomes after surgery for thoracic outlet syndrome. Journal of Vascular Surgery. 2001; 33(6):1220-225. doi: 10.1067/mva.2001.113484

[28] Bosma J, Van Engeland MI, Leijdekkers VJ, Vahl AC, Wisselink W. The influence of choice of therapy on quality of life in patients with neurogenic thoracic outlet syndrome. British Journal of Neurosurgery. 2010; 24(5):532-36. doi: 10.3109/02688697.2010.489656

[29] Chung KC, Burns PB, Sears ED. Outcomes research in hand surgery: where have we been and where should we go? Journal of Hand Surgery. 2006; 31(8):1373-379. doi: 10.1016/j.jhsa.2006.06.012

[30] Cole MB, Tufano R. Appliedtheories in occupational therapy: A practical approach: Thorofare: SLACK Inc; 2008.

[31] Ghoussoub K, Tabet G, Zoghby Z, Jebara V. Rehabilitation of thoracic outlet syndrome: about 60 patients. Lebanese Medical Journal. 2002; 50(5-6):192-96. PMID: 15112847

[32] Yang JL, Lin JJ. Reliability of function-related tests in patients with shoulder pathologies. Journal of Orthopaedic \& Sports Physical Therapy. 2006; 36(8):572-6. doi: 10.2519/ jospt.2006.2133

[33] Schoneveld K, Wittink H, Takken T. Clinimetric evaluation of measurement tools used in hand therapy to assess activity and participation. Journal of Hand Therapy. 2009; 22(3):22135. doi: 10.1016/j.jht.2008.11.005

[34] Roy JS, MacDermid JC, Woodhouse LJ. Measuring shoulder function: a systematic review of four questionnaires. Arthritis \& Rheumatism. 2009; 61(5):623-32. doi: 10.1002/ art.24396

[35] Horn KK, Jennings S, Richardson G, Vliet DV, Hefford C, Abbott JH. The patient-specific functional scale: psychometrics, clinimetrics, and application as a clinical outcome measure. Journal of Orthopaedic \& Sports Physical Therapy. 2012; 42(1):30-42. doi: 10.2519/jospt.2012.3727

[36] Hall AM, Maher CG, Latimer J, Ferreira ML, Costa LO. Thepatient-specific functional scale is more responsive than the Roland Morris disability questionnaire when activity limita- tion is low. European Spine Journal. 2011; 20(1):79-86. doi: 10.1007/s00586-010-1521-8

[37] Kocher MS, Horan MP, Briggs KK, Richardson TR, O'Holleran J, Hawkins RJ. Reliability, validity, and responsiveness of the American Shoulder and Elbow Surgeons subjective shoulder scale in patients with shoulder instability, rotator cuff disease, and glenohumeral arthritis. Journal of Bone and Joint Surgery. 2005; 87(9):2006-011. doi: 10.2106/ jbjs.c.01624

[38] Mahmoudi Hashemi F, Mousavi J, Attarbashi Moghadam B, Talebian Moghadam S, Mousavi SH. [Cross cultural adaptation, Validity and Reliability study of the Persian version of the American shoulder and elbow surgeons (ASES) Questionnaire for evaluation of shoulder functioning injured athletes (Persian)]. Modern Rehabilitation Journal. 2013; 7(1):34-39.

[39] Bot SD, Terwee CB, van der Windt DA, Bouter LM, Dekker J, de Vet HC. Clinimetric evaluation of shoulder disability questionnaires: a systematic review of the literature. Annals of the Rheumatic Diseases. 2004; 63(4):335-41. doi: 10.1136/ ard.2003.007724

[40] Mousavi SJ, Parnianpour M, Abedi M, Askary-Ashtiani A, Karimi A, Khorsandi A, et al. Cultural adaptation and validation of the Persian version of the Disabilities of the Arm, Shoulder and Hand (DASH) outcome measure. Clinical Rehabiltation. 2008; 22(8):749-57. doi: $10.1177 / 0269215508085821$.

[41] Bohnen CL. Outcome measure use in occupational therapy for upper extremity rehabilitation: Results of a survey of therapist clinical practices. Minnesota: Catherine University; 2011.

[42] Al-Hashel JY, El Shorbgy AA, Ahmed SF, Elshereef RR. Early versus late surgical treatment for neurogenic thoracic outlet syndrome. International Scholarly Research Notices Neurology. 2013:673020. doi: 10.1155/2013/673020

[43] Aghaei B, Norouzadeh R, Heidari MR. [Shoulder Pain and Disability Index: validation of Iranian version (Persian)]. Iranian Journal of Breast Disease. 2014; 7(2):16-22.

[44] Davis AM, Beaton DE, Hudak P, Amadio P, Bombardier C, Cole D, et al. Measuring disability of the upper extremity: a rationale supporting the use of a regional outcome measure. Journal of Hand Therapy. 1999; 12(4):269-74. doi: 10.1016/ s0894-1130(99)80063-5

[45] Beaton DE, Richards RR. Measuring function of the shoulder. A cross-sectional comparison of five questionnaires. Journal of Bone \& Joint Surgery. 1996; 78(6):882-90. PMID: 8666606

[46] Povlsen B, Hansson T, Povlsen SD. Treatment for thoracic outlet syndrome. The Cochrane Database of Systematic Reviews. 2014; (11):CD007218. doi: 10.1002/14651858 
